\title{
Potentially inappropriate medication usage, fall and comorbidities in geriatric patients diagnosed with chronic subdural hematoma
}

Kronik subdural hematom tanılı geriatrik hastalarda potansiyel uygunsuz ilaç kullanımı, düşme ve komorbiditeler

\author{
Emin Taşkıran ${ }^{1}$ Gökhan Gürkan ${ }^{2}$ İsmail Ertan Sevin ${ }^{2}$ Zeliha Fulden Saraç ${ }^{1}$ (D) \\ ${ }^{1}$ Ege University Medical Faculty, Department of Internal Medicine and Geriatrics, Izmir, Turkey \\ ${ }^{2}$ Katip Çelebi University Medical Faculty, Department of Neurosurgery, Izmir, Turkey
}

\begin{abstract}
Aim: The annual incidence of chronic subdural hematoma is $2-4 / 100000$ in geriatric population. We aimed to investigate relationship between potentially inappropriate medication usage according to Beers 2019 criteria, fall and Charlson comorbidity index in geriatric patients diagnosed with chronic subdural hematoma.

Materials and Methods: We retrospectively collected medical records of 69 geriatric patients diagnosed with chronic subdural hematoma and hospitalized for the last 5 years in neurosurgery department of Izmir Katip Çelebi University Hospital with the permission of local ethical committee of medical faculty. Data was recorded and analyzed with appropriate method by using SPSS v18.

Results: Mean age was $78.43 \pm 7.51$ years, mean Charlson comorbidity index was $5.87 \pm 2.97$. Falling events were responsible for $59(85.5 \%)$ out of 69 chronic subdural hematoma cases. Potentially inappropriate medication usage according to Beers 2019 criteria was found in 20 (29\%) patients. Inappropriate medications belonged to cardiovascular system (14.5\%) class and antiplatelet/anticoagulant (14.5\%) class mostly. When group was divided into two groups as patients who used potentially inappropriate medication or not, Charlson comorbidity index was found to be higher in the first group. $(p<0.05)$ When group was divided into two groups as patients who fall or not, no correlation was found in Charlson comorbidity index, dementia prevalence, hospitalization duration, number of medications, potentially inappropriate medication, cerebrovascular infarct and hemiplegia prevalence between these groups $(p>0.05)$. Charlson comorbidity index and number of medications showed significant correlation $(p=0.001)$.

Conclusion: We could not reach a significant correlation between fall, Charlson comorbidity index and potentially inappropriate medication usage in our retrospective study. Small study population size, unreliable medical records and relatively healthy characteristics of population may contribute to crossing results.
\end{abstract}

Keywords: Chronic subdural hematoma, geriatrics, fall, comorbidity, inappropriate medication, Beers criteria.

\section{ÖZ}

Amaç: Kronik subdural hematom insidansı, geriatrik yaş grubunda yılda 2-4/100000'dir. Kronik subdural hematom tanılı geriatrik hastalarda, Beers 2019 kriterlerine göre potansiyel uygunsuz ilaç kullanımı ile düşme ve Charlson komorbidite indeksi arasındaki ilişkiyi araştırmayı amaçladık. 
Gereç ve Yöntem: Izmir Katip Çelebi Üniversitesi Hastanesi Beyin ve Sinir Cerrahisi bölümünde son 5 yılda kronik subdural hematom tanısılla yatan 69 hastanın tıbbi kayıtları yerel fakülte etik kurulunun izniyle retrospektif olarak toplandı. Veriler uygun istatistiksel yöntem kullanılarak SPSSv18 programıla analiz edildi.

Bulgular: Hastaların yaş ortalaması 78,43 \pm 7,51 yıl, ortalama Charlson komorbidite indeksi 5,87 \pm 2,97 puandı. Düşme olayları 69 kronik subdural hematom vakasının 59'undan $(\% 85,5)$ sorumluydu. Beers 2019 kriterlerine göre potansiyel uygunsuz ilaç kullanımı 20 hastada (\%29) saptandı. Uygunsuz ilaçlar en çok kardiyovasküler sistem sınıfı $(\% 14,5)$ ve antitrombosit / antikoagulan sınıfa $(\% 14,5)$ aitti. Hastalar potansiyel uygunsuz ilaç kullanımının olup olmamasına göre iki gruba ayrıldığında, Charlson komorbidite indeksi ilk grupta daha yüksek saptandı $(p<0,05)$. Hastalar düşen ve düşmeyenler olarak iki gruba ayrıldığında, Charlson komorbidite indeksi, demans prevalansı, hastanede yatış süresi, ilaç sayısı, potansiyel uygunsuz ilaç kullanımı, serebrovasküler infarkt ve hemipleji varlığı her iki grupta istatistiksel olarak farklı saptanmadı $(p>0,05)$. Charlson komorbidite indeksi ve kullanılan ilaç sayısı arasında önemli istatistiksel ilişki saptandı $(p=0,001)$.

Sonuç: Retrospektif çalışmamızda düşme, Charlson komorbidite indeksi ve potansiyel uygunsuz ilaç kullanımı arasında önemli bir ilişki saptayamadık. Küçük çalışma grubu, retrospektif kayıtların güvenilmez oluşu, çalışma popülasyonun görece sağlıklı karakteristiğe sahip oluşu kafa karıştııcı sonuçlara katkıda bulunmuş olabilir.

Anahtar Sözcükler: Kronik subdural hematom, geriatri, düşme, komorbidite, uygunsuz ilaç, Beers kriterleri.

\section{INTRODUCTION}

Chronic subdural hematoma $(\mathrm{CSH})$ which is caused by either mild trauma or falling is a frequent neurosurgical diagnosis with a global incidence of 2-4 in 100000 per year in elderly people. Aging population, extensive and inappropriate use of antiplatelets or anticoagulants, increasing number of frail elderlies who are at risk for falling and increasing comorbidities with age contribute to raise the incidence of $\mathrm{CSH}$ (1).

Charlson comorbidity index $(\mathrm{CCl})$ was first described in 1987 and started to be used by clinicians to calculate predicted 10-year survival of patients. This calculation demands some information such as age, comorbidities, malignant tumors, hemiplegia etc. As total score increases, survival expectancy lowers (2).

Falling is a geriatric syndrome which causes mortality and morbidity in patients over 65 years old. Complications caused by falling includes femoral neck fracture, vertebrae fracture, operation related complications, venous thrombosis and immobility (3).

Falls were found to be associated with potentially inappropriate medication usage in elderly. Beers 2019 Criteria provided a wide view of probably harmful medications in geriatric population. Extensive and unnecessary use of antiplatelets and anticoagulants, hypnotic and sedative use in patients at risk for falling and antihypertensive overuse in patients at risk for falling are the leading causes for geriatric patients to increase falls (3-5).

We aimed to investigate relationship between potentially inappropriate medication usage according to Beers 2019 criteria, falls and $\mathrm{CCl}$ in geriatric patients diagnosed with $\mathrm{CSH}$.

\section{MATERIAL AND METHOD}

We retrospectively collected medical records of 69 geriatric patients diagnosed with $\mathrm{CSH}$ and hospitalized for the last 5 years in neurosurgery department of Izmir Katip Çelebi University Hospital with the permission of local ethical committee of medical faculty. CSH cases caused by high energy traumas, cases aged below 64 years, cases without available previous medication and comorbidity history were excluded. Patients aged over 64 years and more, diagnosed with $\mathrm{CSH}$ because of low energy traumas were included. Data was recorded to SPSS v18.0. Descriptive analyzes were done. Parametric variables were expressed as mean \pm standard deviation. The groups of parametric variables were compared using the Student's $t$ test and analysis of variance. Also, the groups of nonparametric variables were compared using the Mann- Whitney $U$ test. A value of $p<0.05$ was accepted as statistically significant. 


\section{RESULTS}

Mean age was $78.43 \pm 7.51$ years, mean Charlson comorbidity index was $5.87 \pm 2.97$. The most common comorbidities were hypertension in $37(53.6 \%)$, diabetes mellitus in $16(23.2 \%)$ and heart failure in $16(23.2 \%)$ patients. Falling events were responsible for $59(85.5 \%)$ out of 69 $\mathrm{CSH}$ cases. Potentially inappropriate medication usage according to Beers 2019 criteria was found in $20(29 \%)$ patients. Inappropriate medications belonged to cardiovascular system $10(14.5 \%)$ class and antiplatelet/anticoagulant 10 (14.5\%) class mostly. When group was divided into two groups as patients who used potentially inappropriate medication or not, $\mathrm{CCl}$ was found to be higher in the first group ( $p<0.001)$. Age, falling prevalence, dementia prevalence, hospitalization duration did not differ much among these groups. When group was divided into two groups as patients who fall or not, no correlation was found in $\mathrm{CCl}$, dementia prevalence, hospitalization duration, number of medications, potentially inappropriate medication, cerebrovascular infarct and hemiplegia prevalence between these groups. $\mathrm{CCl}$ and number of medications and $\mathrm{CCl}$ and potentially inappropriate medication usage showed significant correlation $(p=0.001)$, (Table-1).

Table-1. Descriptive of study population.

\begin{tabular}{|c|c|}
\hline Variable & $\mathrm{n}, \%$ or mean $\pm \mathrm{SD}$ \\
\hline Age (years) & $78.43 \pm 7.51$ \\
\hline \multicolumn{2}{|l|}{ Sex } \\
\hline Male $n,(\%)$ & $58(84.1)$ \\
\hline Female n, (\%) & $11(15.9)$ \\
\hline Hospitalization duration (days) & $5.90 \pm 2.55$ \\
\hline $\mathrm{CCl}$ & $5.87 \pm 2.57$ \\
\hline Number of Medication & $1.99 \pm 2.53$ \\
\hline Mortality & 0 \\
\hline CSH cause: trauma/fall & $10(\% 14.5) / 59(\% 85.5)$ \\
\hline \multirow[t]{4}{*}{ Potentially inappropriate medication } & $20(\% 29)$ \\
\hline & $\begin{array}{l}\text { cardiovascular system: } 10(\% 14.5) \\
\text { antiplatelets:/anticoagulants: } 10(\% 14.5)\end{array}$ \\
\hline & $\begin{array}{l}\text { Benzodiazepines in patients at risk for falling: } 1 \\
(\% 1.4)\end{array}$ \\
\hline & $\begin{array}{l}\text { Anti-hypertensives in patients at risk for falling: } 2 \\
(\% 2.9)\end{array}$ \\
\hline \multicolumn{2}{|l|}{ Comorbidities } \\
\hline Diabetes mellitus & $16(\% 23.2)$ \\
\hline Hypertension & $37(\% 53.6)$ \\
\hline Heart failure & $16(\% 23.2)$ \\
\hline Myocardial infarction & $5(\% 7.2)$ \\
\hline Cerebrovascular infarction & $19(\% 27.5)$ \\
\hline Malignant tumor & $8(\% 11.6)$ \\
\hline Dementia & $10(\% 14.5)$ \\
\hline Renal failure & $11(\% 15.9)$ \\
\hline
\end{tabular}

$\mathrm{SD}$, standard deviation; $\mathrm{CCI}$, Charlson Comorbidity Index; $\mathrm{CSH}$, chronic subdural hematoma 


\section{DISCUSSION}

Falls, comorbidities and inappropriate medication usage are major issues in geriatric population which reaches over 8 million people in Turkey in 2019. These issues often accompany each other and each of them increases the risk of $\mathrm{CSH}$ occurrence with low energy traumas in elderly (6, 7). $\mathrm{CSH}$ is the most frequent diagnosis in neurosurgery inpatients. CSH causes morbidity and mortality in affected individuals (8). Thus, prevention of $\mathrm{CSH}$ may be a better aim than to treat.

Beers 2019 criteria listed potentially inappropriate medication in certain diagnosis for elderly people clearly (9). Previous criteria seem to be updated with the new version and provides answers for unknown issues. Potentially inappropriate medication usage: especially as unnecessary antiplatelet/anticoagulant use, unnecessary sedative/hypnotic use in patients at risk for falling, unnecessary anti-hypertensive use in patients at risk for falling may cause balance problems, postural hypotension, eventually falling and easy bleeding with low energy traumas (10, 11). Thus, CSH occurrence may be prevented if relationship between these issues is proved.

We tried to evaluate relationship between potentially inappropriate medication, fall and $\mathrm{CCl}$ in 69 geriatric patients diagnosed with $\mathrm{CSH}$. We detected a correlation between high $\mathrm{CCl}$, number of medications and potentially inappropriate medication usage. Age, falling prevalence, dementia prevalence, hospitalization duration did not differ much by potentially inappropriate medication usage. Falling was not found correlated with dementia prevalence, hospitalization duration, number of medications, potentially inappropriate medication, cerebrovascular infarct and hemiplegia prevalence.

Although there are contrary examples, some of the previous literature suggested that extensive antiplatelet/anticoagulant usage is associated with increased risk of CSH (12-17). We detected that 10 patients with $\mathrm{CSH}(14.5 \%)$ were on inappropriate antiplatelet/anticoagulant therapy in our study. Although our study design did not allow us to analyze additional risk caused by this issue, $14.5 \%$ of the $\mathrm{CSH}$ cases might have been avoided with paying attention. In general, we detected $29 \%$ potentially inappropriate medication usage in study population. It is not easy to define whether this situation caused balance problems, postural hypotension and caused falling or not with our study design. However, we ensure that they all contributed.

Frailty is a geriatric syndrome which defines a clinical situation of reduced endurance to stressors. In aging population, comorbidities are major causes of frailty (18). We tried to evaluate comorbidity burden in $\mathrm{CSH}$ patients with $\mathrm{CCl}$ calculation of each patient. We found a mean $\mathrm{CCl}$ of $5.87 \pm 2.57$ points and significant correlation with number of medications and potentially inappropriate medication usage. It is natural for a person to need more drugs with increasing comorbidities. The important point is that patients should avoid unnecessary medicine and avoid treating side effects of one drug with another which is called as prescription cascade. Geriatricians should follow up drug history of patients in the light of current literature and guidelines.

\section{CONCLUSION}

We did not find a correlation between potentially inappropriate medication, falls and $\mathrm{CCl}$ in geriatric $\mathrm{CSH}$ patients. On the other hand, we detected a correlation between $\mathrm{CCl}$, number of medications and potentially inappropriate medication usage. Potentially inappropriate medication, hospitalization duration, age, sex did not differ much in patients with or without falling event. Limitations of our study are being retrospective, having not a control group and small study population size. This subject needs to be enlighten with large controlled prospective clinical trials.

Conflict of interest: None declared.

\section{References}

1. Kudo H, Kuwamura K, Izawa I, Sawa H, Tamaki N. Chronic subdural hematoma in elderly people: present status on Awaji Island and epidemiological prospect. Neurol Med Chir 1992; 32 (4): 207-9.

2. Charlson ME, Pompei $P$, Ales KL, MacKenzie CR. A new method of classifying prognostic comorbidity in longitudinal studies: development and validation. J Chronic Dis 1987; 40 (5): 373-83. 
3. Pasquetti P, Apicella L, Mangone G. Pathogenesis and treatment of falls in elderly Clin Cases Miner Bone Metab 2014; 11 (3): 222-5.

4. Nam YS, Han JS, Kim JY ,Bae WK, Lee K. Prescription of potentially inappropriate medication in Korean older adults based on 2012 Beers Criteria: a cross-sectional population based study. BMC Geriatr 2016; 16: 118.

5. Harrison SL, Kouladjian L, Crotty D. Costs of potentially inappropriate medication use in residential aged care facilities BMC Geriatr 2018; 18: 9

6. Price SD, Holman CD, Sanfilippo FM, Emery JD. Association between potentially inappropriate medications from the Beers criteria and the risk of unplanned hospitalization in elderly patients. Ann Pharmacother 2014; $48(1): 6-16$.

7. Song Y, Wang Z, Wang LLD, Zhang J. The level of circulating endothelial progenitor cells may be associated with the occurrence and recurrence of chronic subdural hematoma. Clinics (Sao Paulo) 2013; 68 (8): 1084-8.

8. Adhiyaman V, Asghar M, Ganeshram K, Bhowmick B Chronic subdural haematoma in the elderly Postgrad Med J 2002; 78 (916): 71-5.

9. Fick DM, Semla TP, Steinman M, et al. American Geriatrics Society 2019 Updated AGS Beers Criteria $®$ for potentially inappropriate medication use in older adults. J Am Geriatr Soc 2019; 67 (4): 674-94.

10. Wang $\mathrm{H}$, Zhang $\mathrm{M}$, Zheng $\mathrm{H}$ et al. The effects of antithrombotic drugs on the recurrence and mortality in patients with chronic subdural hematoma: A meta-analysis. Medicine (Baltimore) 2019; 98 (1):13972.

11. Tinetti M.E, Han L, Lee DS. Antihypertensive medications and serious fall injuries in a nationally representative sample of older adults. JAMA Intern Med 2014; 174 (4): 588-95.

12. Guha D, Coyne S, Macdonald RL. Timing of the resumption of antithrombotic agents following surgical evacuation of chronic subdural hematomas: a retrospective cohort study. J Neurosurg 2016; 124: 750-9.

13. Aspegren OP, Astrand R, Lundgren MI, Romner B. Anticoagulation therapy a risk factor for the development of chronic subdural hematoma. Clin Neurol Neurosurg 2013; 115: 981-4.

14. Baraniskin A, Steffens C, Harders A, Schmiegel W, Schroers R, Spangenberg P. Impact of pre-hospital antithrombotic medication on the outcome of chronic and acute subdural hematoma. J Neurol Surg A Cent Eur Neurosurg 2014; 75: 31-6.

15. Honda Y, Sorimachi T, Momose H, Takizawa K, Inokuchi S, Matsumae M. Chronic subdural haematoma associated with disturbance of consciousness: significance of acute-on-chronic subdural haematoma. Neurol Res 2015; 37: 985-92.

16. Ohba S, Kinoshita $\mathrm{Y}$, Nakagawa T, Murakami $\mathrm{H}$. The risk factors for recurrence of chronic subdural hematoma. Neurosurg Rev 2013; 36: 145-50.

17. Chon KH, Lee JM, Koh EJ, Choi HY. Independent predictors for recurrence of chronic subdural hematoma. Acta Neurochir 2012; 154: 1541-8.

18. Theou O, Squires E, Mallery K, et al. What do we know about frailty in the acute care setting? A scoping review BMC Geriatr 2018; 18: 139. 